\title{
Verification of Micro electromechanical Sensor Finite-Element Model
}

\author{
D.V. Naumenko ${ }^{1}$, O.A. Ezhova ${ }^{2}$, \\ 1,2, PhD student of Southern Federal University, Russia 44, Nekrasovsky lane, Taganrog, 347928, Russia \\ *Corresponding Author: D.V. Naumenko, PhD student of Southern Federal University, Russia 44, \\ Nekrasovsky lane, Taganrog, 347928, Russia
}

\begin{abstract}
This paper describes the test results of sensitive element of MEMS structures developed in "Techcenter" Southern federal university. The tests were carried out on Polytec MSA-500 equipment with the techniques of scanning Doppler vibrometry and stroboscopic video microscopy in a vacuum chamber. Such tests are standard in the study of amplitude-frequency characteristics of microelectromechanical (MEMS) devices and are relevant for the design of high-precision inertial sensing elements according to the modern trends in the development of MEMS inertial sensors.
\end{abstract}

Mathematical and simulation models were obtained in the early stages of research. These models are used as initial data for development of finite element models. The creating methodology of uniaxial MEMS angular velocity sensor design is described considering technological features of manufacture and its verification before the manufacture of photomasks. Techniques are described which enable to approximate the final model to the calculated ones.

A comparison of the amplitude-frequency characteristics obtained in the numerical experiment conducted using the finite element analysis with the natural experiment results is given. In the course of work we investigated various operation modes of the electrostatic actuator. The minimum allowable pressure for the stable operation of the device and the optimum mode for the excitation of inertial mass were experimentally determined. The influence of the amplitude of the primary and secondary oscillations, q-quality dual axis resonator and the degree of vacuum was studied. Conclusions about the experiment results and the accuracy of the calculations and the plan of further works on the creation of a uniaxial MEMS sensor is given.

Keywords: inertial sensor, characterization MEMS, Polytec MSA-500

\section{INTRODUCTION}

Prospects of modern engineering associated with the development of instruments with a small size, low power consumption, low cost and sufficiently high reliability.

The most dynamically developing microelectromechanical devices (MEMS) are linear acceleration sensors (accelerometers) and angular velocity sensors (gyroscopes). MEMS are used in industry, on land, water and air vehicles. The range of tasks solved by such systems is expanding. Requirements for MEMS for expanding the measuring range, accuracy of parameter determination, minimization of size and power consumption are increasing [1].

Today in our country, the manufacture technical processes of MEMS structures in bulk and surface technologies are mastered. These technologies allow to produce small series of specialized MEMS sensors for non-traditional spheres [2]. These sensors are operated at extreme conditions, such as high acceleration, vibration and shock, temperature extremes, which is typical for such spheres as robotics, aerospace, and oil and gas industries [3-7].

Often, these sensors do not have commercially available counterparts or not available to domestic consumers. The aim of this work is to validate the accuracy of the mathematical and finite element models, calculation methods and computer simulation of the anticipated operating modes. This work is important to continue work in this area and create a more accurate and structural-complicated MEMS sensors. 


\section{The Design of the Sensitive Element of The Mems Angular Velocity Sensor}

The developed sensor elements (SE) of MEMS gyroscopes are structures in the volume of silicon, a diagram of one of them is shown in Figure. 1. In this paper, one of the developed MEMS gyroscope designs with an intrinsic frequency of $5 \mathrm{kHz}$ is described.

The main parameters of the MEMS gyroscope sensing element are shown in Table 1.

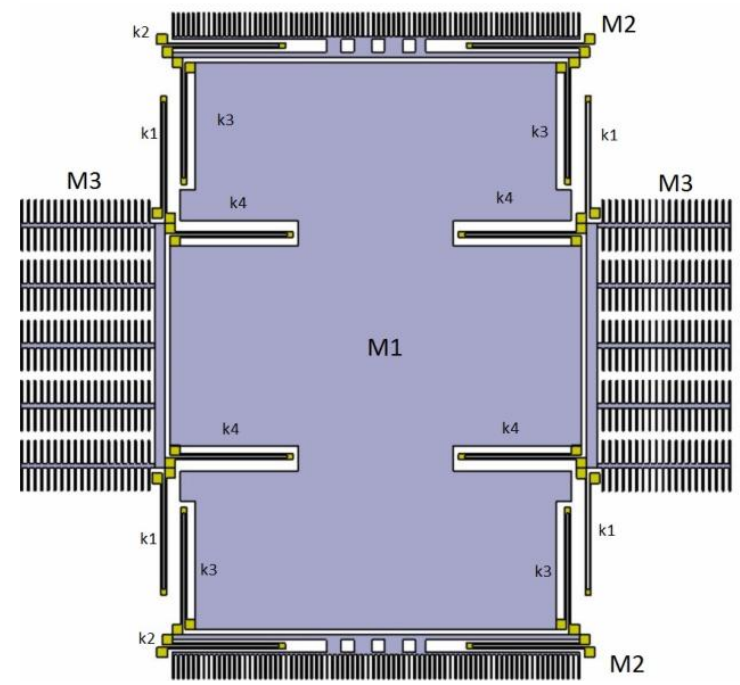

Figure1. Structural diagram of a sensing element of a MEMS gyroscope

Table1. Basic design parameters of the sensing element of the MEMS

\begin{tabular}{|l|l|}
\hline Parameter & Value \\
\hline Working layer material & Silicon100 \\
\hline Young's modulus & $169 \mathrm{GPa}$ \\
\hline Working layer thickness & $50 \mu \mathrm{m}$ \\
\hline Substrate material & Pyrex \\
\hline Substrate Thickness & $400 \mu \mathrm{m}$ \\
\hline Material of contact pads & aluminum \\
\hline Size of contact pads & $200 \mathrm{x} 200$ \\
\hline Thickness of the metallization layer & $2 \mu \mathrm{m}$ \\
\hline The magnitude of the air gap between the information electrodes & $2 \mu \mathrm{m}$ \\
\hline The width of elastic suspensions & $5 \mu \mathrm{m}$ \\
\hline The width of the fingers of the electrostatic drive & $3 \mu \mathrm{m}$ \\
\hline Aspect ratio & $1: 50$ \\
\hline Lining capacity & $2 \mathrm{pF}$ \\
\hline Natural frequency in motion mode & $4760 \mathrm{~Hz}$ \\
\hline Natural frequency in sensitivity mode & $4954 \mathrm{~Hz}$ \\
\hline The natural frequency of the parasitic waveform & $7846 \mathrm{~Hz}$ \\
\hline Amplitude of inertial mass oscillations & $1,5 \mu \mathrm{m}$ \\
\hline Quality & 100 \\
\hline DC & $5 \mathrm{~V}$ \\
\hline Variable component of electrostatic actuator voltage & $+/-5 \mathrm{~V}$ \\
\hline
\end{tabular}

In the volume of silicon electrical and micromechanical structures are integrated providing oscillation of the inertial mass due to comb, counter-pin electrostatic actuators. Reading of information is performed by using capacitive elements with a variable gap. The electrostatic drive rotor and movable combs of the capacitive information converter are connected by an elastic suspension to the inertial mass. At the first stage it was decided to abandon the use of intermediate frames in the suspension of the MEMS gyroscope due to the high requirements for the accuracy of manufacturing devices. It would also complicate the construction and verification of the model, since the structures developed were made for the first time.

To reduce of the quadrature parasitic signal extreme information combs were reduced as in case of movement they have the largest amplitude. It is shown in a figure 2. 


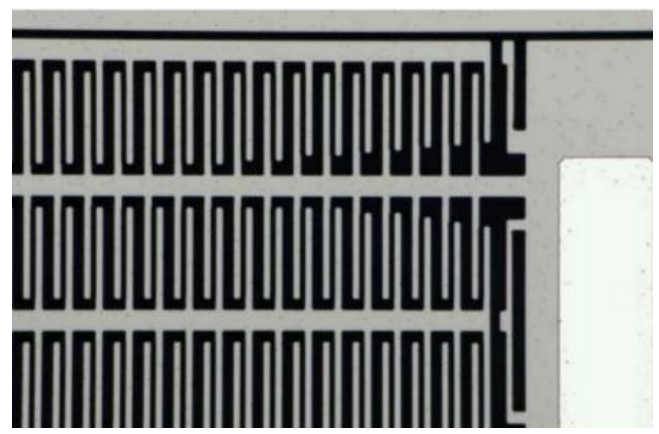

Figure2. Reduced combs and locking elements under a microscope.

\section{FEATURES OF MEMS GYROSCOPE DESIGNING}

When developing MEMS gyroscopes, it is necessary to obtain the dynamic characteristics of the sensitive elements that were laid during the development of the mathematical model [8]. This can be prevented by various reasons $[9,10]$. The mathematical model of the sensing element of the MEMS gyroscope is a system of differential equations [11-15]

$\left\{\begin{array}{l}\ddot{x}+2 \cdot \delta \cdot \dot{x}+\omega_{1}^{2} \cdot x=\left(F_{e l 2}-F_{e l 1}\right) \cdot m^{-1}+F_{x} \cdot m^{-1}+\Omega \cdot(\dot{y}+\Omega \cdot x) ; \\ \ddot{y}+2 \cdot \delta \cdot \dot{y}+\omega_{2}^{2} \cdot y=F_{k} \cdot m^{-1}+\left(F_{e l 4}-F_{e l 3}\right) \cdot m^{-1}+F_{y} \cdot m^{-1}-\Omega(\dot{x}-\Omega \cdot y) .\end{array}\right.$

where $\mathrm{x}, \mathrm{y}$-movements of the sensing element along the $\mathrm{X}$ and $\mathrm{Y}$ axes; $\mathrm{m}$ - the mass of the sensing element; $\beta$ - coefficient of damping; $\omega 01, \omega 02$ - natural frequencies of oscillations of the sensing element along the $\mathrm{X}$ and $\mathrm{Y}$ axes; Fel1, Fel2 - electrostatic force; Fk - the Coriolis inertia force; Fx, Fy - the forces of inertia; $\Omega$ - the angular velocity.

It is necessary to provide equality of resonance frequencies of primary and information oscillations that is necessary to increase sensitivity of a gyroscope [16]. The natural frequencies of the system are defined by the equations:

$\left\{\begin{array}{l}\omega_{1}=\sqrt{\frac{k-k_{e l 1}}{m}}=\sqrt{\omega_{01}^{2}-\frac{k_{e l 1}}{m}} ; \\ \omega_{2}^{2}=\sqrt{\frac{k-k_{e l 2}}{m}}=\sqrt{\omega_{02}^{2}-\frac{k_{e l 2}}{m} .}\end{array}\right.$

The stiffnesses of the elastic elements were calculated analytically by various methods $[11,12,17]$, after which a static calculation was conducted with the finite element method.

Some complex software products, such as CoventorWare, MEMSCAP, IntelliSuite, Mems Pro, exist to design micromechanical devices using computer. The use of such products products is justified in the case of mass design, support for serial MEMS products, but it is not justified for single development. Also, we should mention that employees need to undergo additional training when working with this software, as there are not training or trial versions of these products. Thus it is necessary to use the available software $[1,18]$.

Before the manufacture of photomasks when assembling and designing of MEMS devices changes in the design must be made according to technological features of the manufacture. Also functional elements (anchors, stops, damping elements, elements preventing electrostatic sticking) should be added, which were not taken into account in the developed mathematical model. This entails changes in the shape and size of the inertial masses, the rigidity of the elastic elements, which affect the dynamic characteristics of the final device.

\section{DYNAMIC CHARACTERISTICS OF MEMS GYROSCOPE}

One of the main research allowing to determine the natural frequency and shape of oscillations is the modal analysis $[19,20]$. The design of the MEMS sensitive element has 2 basic oscillations modes: the motion mode and the sensitivity mode. The remaining modes should have big natural frequency not to introduce additional interference into the device operation.

Below are illustrations of vibration modes and deformation of elastic suspension elements. 


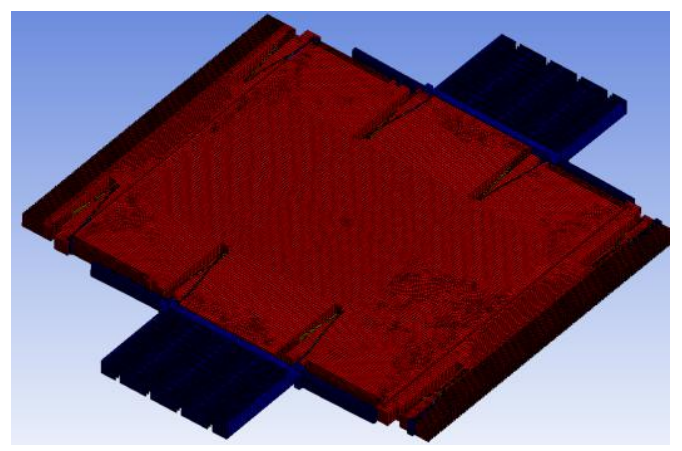

Figure3. Primary oscillations at a frequency of $4760 \mathrm{~Hz}$

One of the frequencies of natural oscillations can be raised by adding electrostatic rigidity by applying a constant voltage to the electrostatic actuator plates or information electrodes, depending on the control scheme, which should be taken into account in the design.

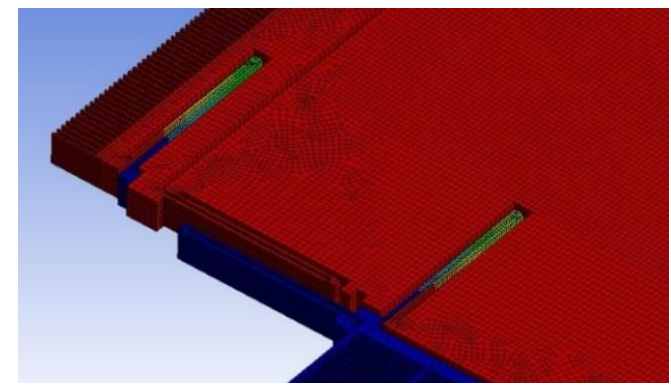

Figure4. The deformation of the elastic elements at primary oscillations

The permissible difference between primary and secondary oscillations is of the order of $50-100 \mathrm{~Hz}$.



Figure5. Deformation of elastic elements under information oscillations

If the frequency of the undesired vibration modes is lower than the frequency of the primary oscillations of the inertial mass, then minor manufacturing defects or device external interference will have a large signal parasitic component, which is difficult to deal with during processing.

\section{Receiving of Preliminary Amplitude-Frequency Characteristics}

The next step to determine the dynamic characteristics is to conduct harmonic analysis.

Harmonic analysis is used to find the steady-state response of linear systems loaded with sinusoidal forces. Cyclic loading leads to a harmonic reaction of mechanical systems. The calculation is performed by finding the response of the system at several frequencies and plotting the amplitudefrequency characteristics. The maximum of the reaction, found according to the schedule, corresponds to the maximum stress in the structure. Harmonic analysis is designed to find the maximum value of the levels of steady-state vibration. Transient processes are not evaluated in this type of analysis.

Harmonic analysis is a linear analysis. Some non-linearities, such as plasticity, contact phenomena, or gaps, are ignored, even if they are defined in the system.

Harmonic analysis can be used for prestressed structures, such as the violin string (assuming that the voltage from the harmonic load is substantially less than the prestress voltage).

There are three methods of analysis: complete, truncated, and the method of superposition of modes $[19,20]$. 
The method of superposition of modes was used in the calculations. Modes and natural frequencies are obtained by conducting modal analysis. Force action corresponds to the strength of the electrostatic actuator. The results of the harmonic analysis are presented in Figure 9.


Figure6. Amplitude-frequency characteristics of primary oscillations of MEMS gyroscope as a result of computer analysis

\section{CONDUCTIng ReSEarches of Manufactured Structures}

The structures were manufactured in cooperation with the Russian Association MEMS (RAMEMS) in Kursk using the technology of deep reactive ion etching (BDRIE). These structures were examined using an electron microscope. Measurements of elastic elements were made and technological manufacturing errors were estimated. Several structures were deliberately destroyed to test the thickness of the instrument layer and the depth of the cavity beneath the structure. (Figure 7)

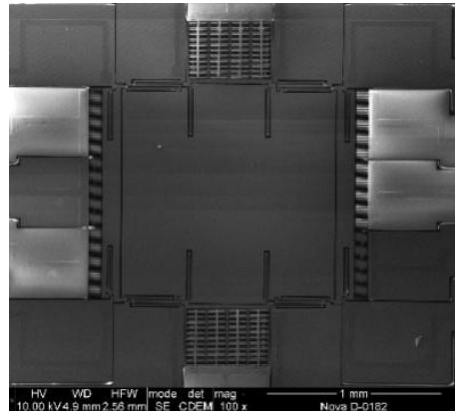

General view of the structure

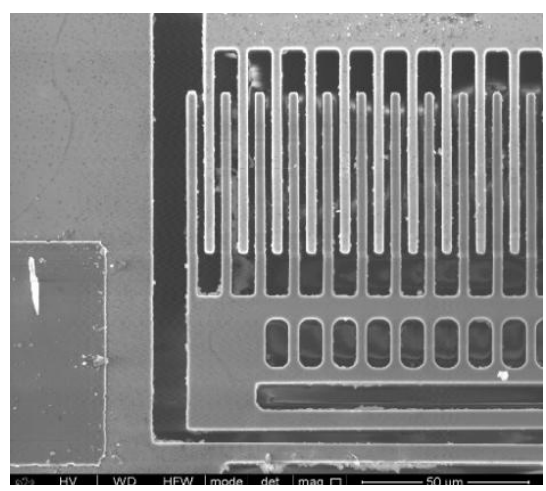

Electrostatic actuator combs



Inertial mass with information converter

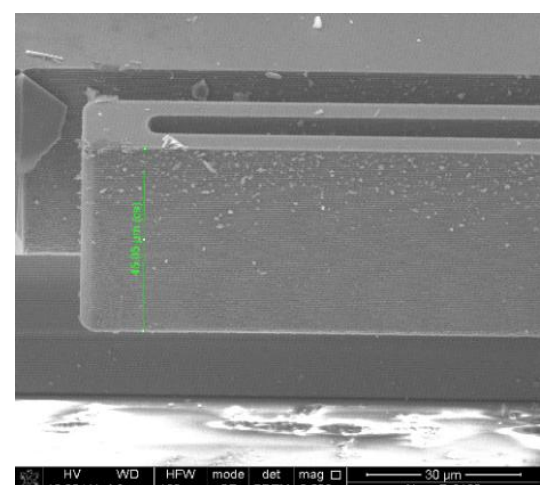

Measurement of the height of the elastic element

Figure7. Images from an electron microscope 
Pre-encapsulated sensing elements (Figure8) were examined using a microsystem analyzer Polytec MSA-500



Figure8. Sensor element of MEMS gyroscope in cermet casing

The MSA-500 microsystem analyzer (Figure9) is a single measuring station for the high-precision determination of the three-dimensional dynamic characteristics of MEMS and MOEMS structures.

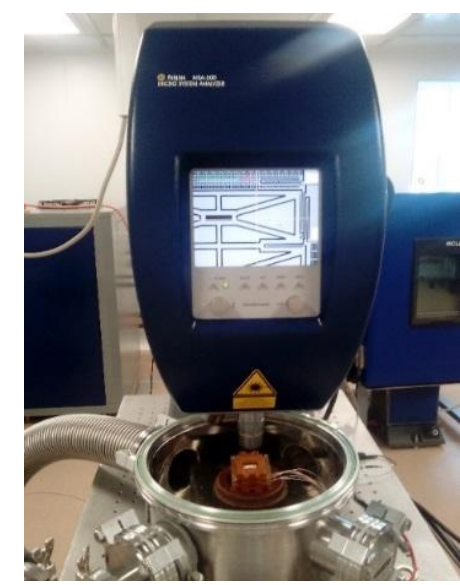

Figure9. Installation of the test samples in a vacuum chamber at Polytec MSA-500

In the study of the samples, laser scanning vibrometry techniques were used to investigate spatial vibration behavior and at a point on a sample and stroboscopic video microscopy to accurately measure high-frequency oscillations in the plane when testing the device, when using stroboscopic illumination and a digital image, rapid periodic movements of the object can be instantaneously stopped for capture of the position in the region of interest in the sample [21, 22].

The result of a stroboscopic video microscopy is the acquisition of a video fragment of the real movement of the structure. The technical characteristics of the microsystem analyzer are given in Table 2.

Table2. Microsystem Analyzer Specifications

\begin{tabular}{|c|c|}
\hline Lateral vibration measurements & \\
\hline Measured value & instantaneous speed and vibration \\
\hline Light source & $\begin{array}{l}\text { LED with a long life, wavelength of } 525 \mathrm{~nm} \text {, } \\
\text { coherence length } \sim 8 \mu \mathrm{m} ;\end{array}$ \\
\hline Frequency range of vibration & $0-24 \mathrm{MHz}$ \\
\hline Permission to move, not worse & $<0.1 \mathrm{pm} / \sqrt{ } \mathrm{Hz}$ \\
\hline Max. vibration speed (peak), no less than & $\pm 10 \mathrm{~m} / \mathrm{s}$ \\
\hline Speed resolution, not worse & $<1 \mu \mathrm{m} / \mathrm{s}$ \\
\hline $\begin{array}{l}\text { Measurement of vibration in the plane of the } \\
\text { object }\end{array}$ & \\
\hline Frequency range of vibration & $1 \mathrm{~Hz}-1 \mathrm{MHz}$ \\
\hline Permission to offset, not worse & $1 \mathrm{~nm}$ \\
\hline Resolution on time, not worse & $100 \mathrm{~ns}$ \\
\hline Max vibration speed (peak) & $\begin{array}{l}>0,1-10 \mathrm{~m} / \mathrm{s} \text { (depending on the } \\
\text { magnification) }\end{array}$ \\
\hline
\end{tabular}


As a result of the study, the amplitude-frequency characteristics of MEMS elements for different degrees of evacuation and the parameters of the электростатик actuator are obtained.

Figure 10 shows an example of an investigation at a pressure of $2000 \mathrm{~Pa}$, the amplitude of an electrostatic drive in $2 \mathrm{~V}$ and a reference voltage of $5 \mathrm{~V}$.

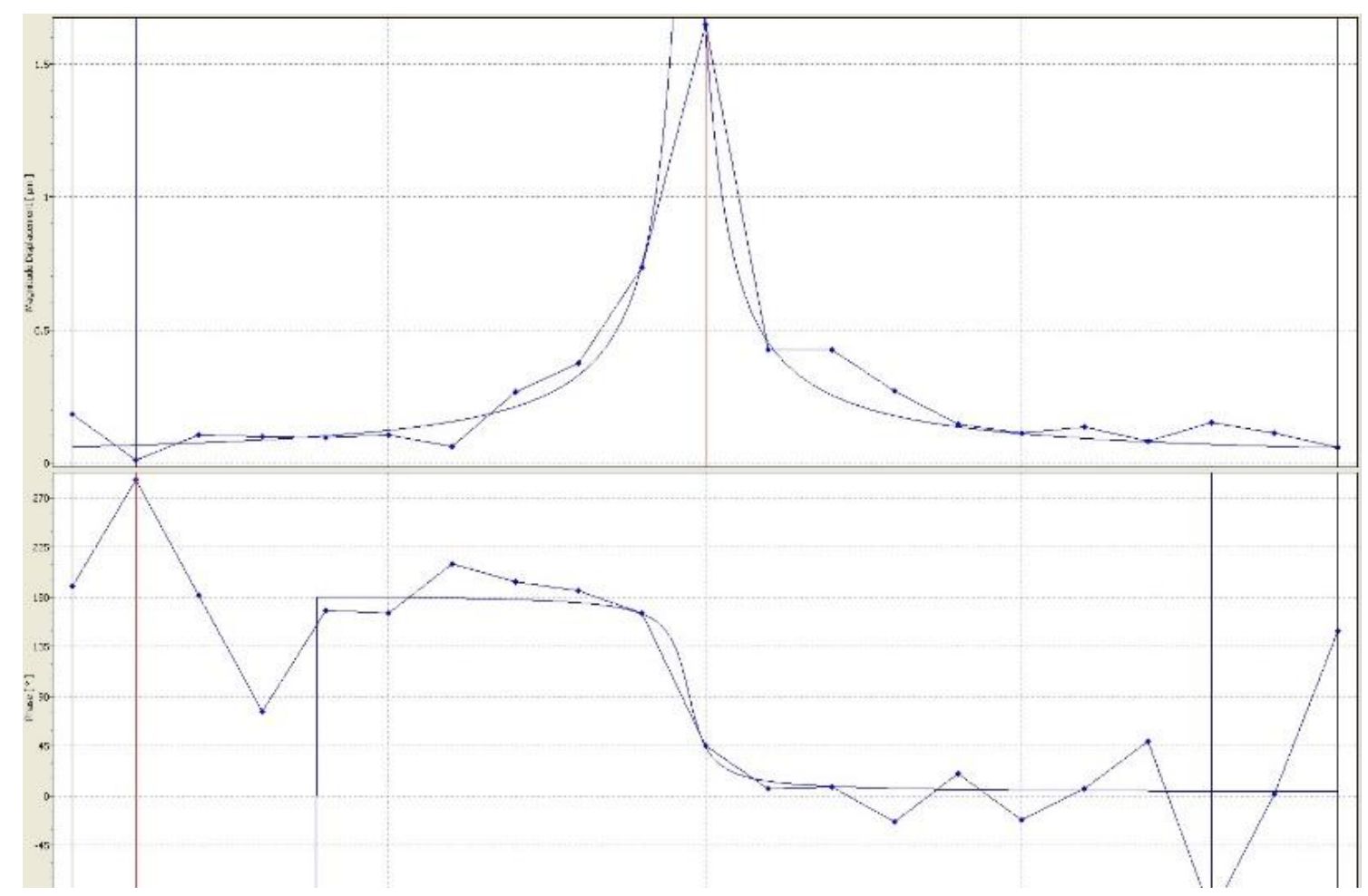

\begin{tabular}{|c|c|}
\hline Pattern A - & \\
\hline Frequency & \\
\hline 1: & $4700.000 \mathrm{~Hz}$ \\
\hline 2: & $4900.000 \mathrm{~Hz}$ \\
\hline - Magnitu & acement \\
\hline 1: & $0.182 \mu \mathrm{m}$ \\
\hline $2:$ & $0.059 \mu \mathrm{m}$ \\
\hline Min: & $4710.000 \mathrm{~Hz}$ \\
\hline & $0.012 \mu \mathrm{m}$ \\
\hline Max: & $4800.000 \mathrm{~Hz}$ \\
\hline & $1.646 \mu \mathrm{m}$ \\
\hline Mean Value: & $0.266 \mu \mathrm{m}$ \\
\hline$\sigma:$ & $0.350 \mu \mathrm{m}$ \\
\hline$-3 \mathrm{~dB}:$ & $4.749930 \mathrm{~Hz}$ \\
\hline$f$ max: & $4797.437 \mathrm{~Hz}$ \\
\hline - Phase & \\
\hline 1: & $189.6^{\circ}$ \\
\hline 2: & $148.9^{\circ}$ \\
\hline Min: & $4880.000 \mathrm{~Hz}$ \\
\hline & $-107.7^{\circ}$ \\
\hline Max: & $4710.000 \mathrm{~Hz}$ \\
\hline & $2856^{\circ}$ \\
\hline
\end{tabular}

Figure10. Experimentally obtained amplitude-frequency characteristic of primary oscillations of MEMS gyroscope as a result of full-scale experiment

As we can see, the result of the full-scale experiment coincides with the admissible accuracy with the characteristics obtained during finite element analysis. The results of the comparison are given in Table 3 
Table3: Comparison of the characteristics obtained in the simulation with the experimental results

\begin{tabular}{|l|c|c|c|}
\hline Parameter & Nominal value & Estimated value & The experimental value \\
\hline $\begin{array}{l}\text { The natural frequency in the } \\
\text { motion mode }\end{array}$ & $5000 \mathrm{~Hz}$ & $4760 \mathrm{~Hz}$ & $4800 \mathrm{~Hz}$ \\
\hline $\begin{array}{l}\text { the natural frequency in the } \\
\text { sensitivity mode }\end{array}$ & $5000 \mathrm{~Hz}$ & $4954 \mathrm{~Hz}$ & $5035 \mathrm{~Hz}$ \\
\hline $\begin{array}{l}\text { Amplitude of oscillations of } \\
\text { inertial mass }\end{array}$ & $1,5 \mu \mathrm{m}$ & $1,5 \mu \mathrm{m}$ & $1.646 \mu \mathrm{m}$ \\
\hline Quality voltage of & 100 & 100 & $5 \mathrm{~V}$ \\
\hline $\begin{array}{l}\text { Constant } \\
\text { electrostatic actuator }\end{array}$ & $5 \mathrm{~V}$ & $52 \mathrm{~V}$ \\
\hline $\begin{array}{l}\text { Variable component of the } \\
\text { voltage of the electrostatic } \\
\text { drive }\end{array}$ & $\pm 5 \mathrm{~V}$ & $\pm 5 \mathrm{~V}$ & \\
\hline
\end{tabular}

\section{CONCLUSiON}

Despite the simple single-mass design and the absence of an additional intermediate frame, the design showed stable operation under design operating conditions.

The finite element analysis was conducted with high accuracy. The error in calculating the natural frequencies and the amplitude of the oscillations did not exceed $5 \%$.

In further calculations, it is necessary to use the preload created by a DC-voltage on the electrostatic actuator to determine the possibility of an accurate resonance tuning of the driving mode and sensitivity mode. Experimental studies of the effect of temperature on the dynamic characteristics of MEMS structures are planned to verify temperature calculations.

Further work is planning to be related to the creation of a specialized scheme for processing inertial information, since the accuracy in the removal and correctness of further processing of information from the sensitive MEMS element will have a great influence on the accuracy of the MEMS gyroscope.

At the next stage, the production of multi-mass structures in accordance with current trends in the development of MEMS gyroscopes is planned [23-27]. The use of an intermediate frame will reduce the influence of primary oscillations on capacitive information structures, thereby the absolute magnitude of quadrature interference will decrease, the system for processing the output information will be simplified and the accuracy of measuring the angular velocity of the object under study will increase.

The work was done on the basis of STC Technocenter in cooperation with the NTMST SFedU department.oбработкивыходнойинформациииповыситсяточностьизмеренияугловойскоростиисс ледуемогообъекта.

\section{REFERENCES}

[1] Barbin E.S., Baranov P.F., Koleda A.N., Nesterenko T.G.,. Peresvetov M.V Modelirovaniye konstruktsionnykh i dinamicheskikh kharakteristik dvukhkomponentnogo mikromekhanicheskogo giroskopa. [Modeling of constructional and dynamic characteristics of a two-component micromechanical gyroscope] Vestnik nauki Sibiri. — 2013. — № 1 (7). — [S. 96-105]

[2] Yevstifeyev M. I. Osnovnyye etapy razrabotki otechestvennykh mikromekhanicheskikh giroskopov [The main stages of the development of domestic micromechanical gyroscopes] // Izv. vuzov. Priborostroyeniye. 2011. T. 54, № 6. S. $75-80$.

[3] Timoshenkov S.P., Kul'chitskiy A.P. Primeneniye MEMS-sensorov v sistemakh navigatsii i oriyentatsii podvizhnykh obyektov [Application of MEMS sensors in navigation systems and orientation of mobile objects] // Nano - i mikrosistemnaya tekhnika. 2012. №6. S. 51 - 56.

[4] Aravin V.V., Verner V.D., Saurov A.N., Mal'tsev P.P. MEMS vysokogo urovnya - vozmozhnyy put' razvitiya MEMS v Rossii [High-level MEMS - a possible path for the development of MEMS in Russia] // Nano - i mikrosistemnaya tekhnika. 2011. №6. S. 28 - 31.

[5] Prokof'yev I.V., Tikhonov R.D. Nano - i mikrosistemy dlya monitoringa parametrov dvizheniya transportnykh sredstv [Nano - and microsystems for monitoring the traffic parameters of vehicles] // Nano - i mikrosistemnaya tekhnika. 2011. №12. S. 48 - 50.

[6] Anchurin S.A., Maksimov V.N., Morozov Ye.S., Golovan' A.S., Shilov V.F. Blok inertsial'nykh datchikov [Block of inertial sensors] // Nano - i mikrosistemnaya tekhnika. 2011. №1. S. 50 - 53.

International Journal of Research Studies in Electrical and Electronics Engineering (IJRSEEE) Page | 26 
[7] Sysoyeva S. Klyuchevyye segmenty rynka MEMS-komponentov [Key market segments MEMScomponents] // Komponenty i tekhnologii. -2010. - № 5. - S. 35-42.

[8] Lysenko I.Ye., Sinyutin S.A., Voronkov O.YU. Razrabotka povedencheskoy modeli sensora lineynogo uskoreniya s dvumya osyami chuvstvitel'nosti dlya modelirovaniya v srede Simulink programmnogo paketa MatLab[Development of a behavioral model of a linear acceleration sensor with two sensitivity axes for simulation in the Simulink] / Inzhenernyy vestnik Dona, №4 (2014).

[9] Nesterenko T.G., Peresvetov M.V. Vliyaniye tipovykh defektov na dinamicheskiye kharakteristiki mikromekhanicheskogo giroskopa LL-tipa [Influence of typical defects on the dynamic characteristics of the micromechanical gyroscope LL-type] // Aviakosmicheskoye priborostroyeniye. -2012. - № 4. - S. 310 .

[10] Kulikova I.V.. Lysenko I.Ye. Pristupchik N.K . Naumenko D.V

[11] Metodika rascheta vliyaniya termouprugikh napryazheniy na dinamicheskiye kharakteristiki MEMS [A procedure for calculating the effect of thermoelastic stresses on the dynamic characteristics of MEMS]./Inzhenernyy vestnik Dona, 2015, №3

[12] C. Acar and A. Shkel, "MEMS vibratory gyroscopes-Structural approaches to improve robustness," in MEMS Reference Shelf Series. New York: Springer, 2009, ISBN: 978-0-387-09535-6.

[13] Lysenko I.Ye. Proyektirovaniye sensornykh i aktyuatornykh elementov mikrosistemnoy tekhniki [Designing sensory and actuating elements of microsystem technology]. Taganrog: Izd-voTRTU, 2005. $103 \mathrm{~s}$.

[14] Lysenko, I.E., 2013. Modeling of the micromachined angular rate and linear acceleration sensors LL-type with redirect of drive and sense axis. World Applied Sciences Journal, 27 (6): 759 - 762.

[15] Konoplev B.G., Lysenko I.Ye., Sherova Ye.V. Integral'nyy sensor uglovykh skorostey i lineynykh uskoreniy [ntegral sensor of angular velocities and linear accelerations]// Inzhenernyy vestnik Dona, 2010, №3

[16] Lysenko I.Ye., Yezhova O.A. Kriterii ravenstva sobstvennykh chastot kolebaniy chuvstvitel'nykh elementov mikromekhanicheskikh giroskopov-akselerometrov [Criteria for Equality of the Natural Frequencies of Oscillations of Sensitive Elements of Micromechanical Gyroscopes-Accelerometers]// Inzhenernyy vestnik Dona, 2014, №2A.

[17] V. Shaporin, M. Hanf, and W. Doetzel, "Novel characterization method for MEMS devices," in Proc. SPIE, 2005, vol. 5716, pp. 198-206.

[18] Timoshenko S.P. Soprotivleniye materialov [Strength of materials]. Tom 1. Izd. 2-ye, stereotip., Per. s angl. V.N.Fedorova. - M.: Nauka, 1965. - $363 \mathrm{~s}$

[19] Yashin K.D., Latsapnov Ye.V., Osipovich V.S. Sistemy avtomatizirovannogo proyektirovaniya MEMS [Automated Design Systems MEMS] // Informatsionnyye tekhnologii. - 2007. -№11. - s . 22-28

[20] Bruyaka V.A., Fokin V.G., Kurayeva YA.V. Inzhenernyy analiz v Ansys Workbench [Engineering Analysis in Ansys Workbench]: Samara, 2013. - 149 s.

[21] Leont'yev N.V. Primeneniye sistemy ANSYS k resheniyu zadach modal'nogo i garmonicheskogo analiza [Application of the ANSYS system to solving modal and harmonic analysis problems]. Nizhniy Novgorod, 2006, $101 \mathrm{~s}$

[22] Shaporin A. V., Hanf M., and Doetzel W., "Novel characterization method for MEMS devices," in Proc. SPIE, 2005, vol. 5716, pp. 198-206.

[23] Rembe C., Siegmund G., Steger H., and Wörtge M., "Measuring MEMS in Motion by Laser-Doppler Vibrometry," in Optical Inspection of Microsystems, Optical Science and Engineering Series, W. Osten, Ed. New York: Taylor \& Francis, 2006, pp. 245-292.

[24] Alper, S.E., K. Azgin and T. Akin, 2007. A high-performance silicon-on-insulator MEMS gyroscope operating at atmospheric pressure. Sensors and Actuators A, 135: $34-42$.

[25] Acar et al. United States Patent 9,062,972: Mems multi -axis accelerometer electrode structure (June 23, 2015) // United States patent and trademark office.

[26] Nasiri et al. United States Patent 8,960,002: Vertically integrated 3-axis MEMS angular accelerometer with integrated electronics (February 24, 2015) // United States patent and trademark office.

[27] Cenk Acar and Andrei M. Shkel. Structurally decoupled micromachined gyroscopes with post-release capacitance enhancement. J. Micromech. Microeng, 15(2005), pp. 1092-1101, doi:10.1088/0960$1317 / 15 / 5 / 028$

[28] Dunzhu Xia, Cheng Yu and Lun Kong. The Development of Micromachined Gyroscope Structure and Circuitry Technology // Sensors, 2014, 14, pp. 1394-1473, doi:10.3390/s140101394. 


\section{AUTHORS' BIOGRAPHY}

Danil V. Naumenko, PhD student of Southern Federal University, Russia 44, Nekrasovsky lane, Taganrog, 347928, Russia

Danil V. Naumenko graduated from the Southern Federal University in 2011.Since 2014, he has been developing the MEMS device as an engineer. In 2015 underwent advanced training "Micromechanical Inertial Sensors: Theory and Design" at the Tula State University. Since 2017, is a graduate student at the Southern Federal University, Taganrog. His research interests include micromechanical gyroscopes and accelerometers.

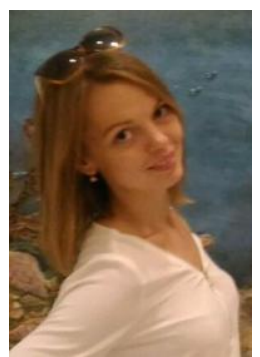

Olga A. Ezhova, PhD student of Southern Federal University, Russia 44, Nekrasovsky lane, Taganrog, 347928, Russia

Olga A. Ezhova received the BSc degree in microsystem technology at Southern Federal University, Taganrog, Russia, in 2012 and the MSc degree at the same university and the same area of study in 2014. Currently, she is a postgraduate student and works at Southern Federal University. Her research interests include micromechanical angular velocities and linear acceleration sensors.

Citation: D.V. Naumenko,\& O.A. Ezhova,.(2017). Verification of Micro electromechanical Sensor FiniteElement Model, International Journal of Research Studies in Electrical and Electronics Engineering (IJRSEEE), 3(4), pp.19-28, DOI: http://dx.doi.org/10.20431/2454-9436.0304004.

Copyright: (C) 2017 D.V. Naumenko,\& O.A. Ezhova. This is an open-access article distributed under the terms of the Creative Commons Attribution License, which permits unrestricted use, distribution, and reproduction in any medium, provided the original author and source are credited 